\title{
Credit Risk, Capital, and Inefficiency: An Empirical Analysis of SAARC Banking Sector
}

\author{
Shumaila Zeb * $\quad$ Zahid Ali ${ }^{\dagger}$
}

\begin{abstract}
The main purpose of this study is to investigate the relationship between credit risk, capital, and inefficiency of South Asian Association for regional Cooperation (SAARC) banks. The study used seemingly unrelated regressions (SUR) approach on panel data for the period 2010-2016. The findings suggest that highly capitalized banks tend to increase inefficiency and credit risk faced by SAARC banking sector. There are no major differences in relationship between credit risk, capital, and inefficiency in SAARC banks. The findings suggest that regulators and policy makers may need to assess the relationship between credit risk, capital, and efficiency while designing banking regulations.
\end{abstract}

Keywords: Bank capital; efficiency; credit risk; net lending; SAARC banks.

JEL Classification: G21; G32; G38; H2

\section{Introduction}

Banks play a significant role in the economic development of a country. The most important component of banking sector is commercial banks. Commercial banks are involved in capital formation, funds channelization to productive investment, and efficient utilization of resources to encourage right type of industries. Therefore, they have to be efficient enough to boost the development of an economy in the long run. Globalization and technological advancements increase pressure on the banks to maintain high market shares, not only for survival but for gaining competitive edge as well. Competition from domestic and foreign banks also exerts pressure on the banks to perform efficiently. Therefore, commercial banks need not only to be profitable but efficient as well (Lee \& Hsieh, 2013).

Certain financial regulations are imposed on commercial banks with an aim to increase profitability and efficiency, and decrease the overall risk exposures. The most important financial regulation is on bank capital because it plays a vital role in risk taking activities and overall health of commercial banks. More stable and highly capitalized banks undergo more risky activities (Chen, Wu, Jeon, \& Wang, 2017). Therefore, the risk management process of banks is aimed at utilizing capital efficiently for obtaining maximum benefits at the minimum cost of capital.

\footnotetext{
${ }^{*}$ Shaheed Zulfikar Ali Bhutto Institute of Science and Technology, Islamabad Campus, Islamabad, Pakistan

E-mail: E-mail: shumaila.zeb@gmail.com

†Shaheed Zulfikar Ali Bhutto Institute of Science and Technology, Islamabad Campus, Islamabad, Pakistan.

E-mail: zahidalisays@gmail.com
} 
In the previous literature we can find handful papers on the developing economies. For example, Witowschi and Luca (2016), Baselga-Pascual, L, and Cardone-Riportell (2015) and Jokipii and Milne (2011) investigated the relationship between efficiency and risk exposures in European and US banks. However, the empirical evidence is still not in abundance for the South Asian banks. Consequently, current study attempts to fill this gap in the literature by providing the empirical evidence on the banking sector of South Asia Associations for Regional Cooperation (SAARC). SAARC member countries include Pakistan, India, Bangladesh, Sri Lanka, the Maldives, Nepal, Afghanistan, and Bhutan. This alliance aims at accelerating the economic cooperation and integration of the member countries through joint collaboration. Inter-linkages of different banks and financial institutions have played an important role in shaping this alliance. Keeping in light the main rational of SAARC, the main objective of this study is to investigate the relationship between credit risk, capital and inefficiency of 107 SAARC banks. For this purpose, Seemingly Unrelated Regression (SUR) approach is used for the period of 2010-2016.

This study calculates bank inefficiency as cost to income ratio, risk as a loan loss reserves to total assets, and bank capital as equity to total assets. The bank-specific variables included in the study are bank size, return on assets, liquidity and net lending. The country-specific variables used in the study are banking system interest rate spread, banking system cost, return on capital, and banking system liquidity.

Our findings reveal that increase in bank capital makes the bank inefficient and also increase the credit risk of the banks. Taken together, bank capital and credit risk of banks both are significantly related to the inefficiency level of banks. The results are significant for management and regulatory authorities in formulating policies to strengthen the banking sector of SAARC member countries. Moreover, policy makers may plan such strategies that help the banks to increase their efficiency level and reduce the risk taken by them. This study provides new evidence on the relationship between credit risk, capital, and inefficiency in SAARC banking sector.

\section{Literature Review}

The regulators and policy makers have increased their focus on capital adequacy of banking sectors to improve stability of financial system. However, it is the need of time to emphasize the effects of bank capital requirement on bank risk and efficiency. To answer this question more precisely, the Basel Committee on Banking Supervision (BCBS) has updated the guidelines for banking regulations. Basel III has proposed several new capital, liquidity, and leverage standards to strengthen supervision, management, and regulation of risk in the banking sector.

Some previous research studies examined the relationship between efficiency, risk, and capital. For example, Miah and Sharmeen (2015) found a significant relationship between risk, capital, and efficiency in Islamic and conventional banks of Bangladesh for the period 2001-2011 using SUR model. They found that capital level was significantly related to the risk of Islamic banks. The results showed that highly capitalized banks indulge in more risky activities. The capital of conventional banks was not related to risk. Moreover, 
they found a negative relationship between efficiency and capital in Islamic banks. They also found that risk was negatively related to bank efficiency. The inefficient conventional banks took more risk because they needed more resources to manage and monitor existing portfolio which raised their operating cost.

In the same manner, Altunbas, Carbo, Gardener, and Molyneux (2007) examined the relationship between capital, risk, and efficiency in the European banks for the period 1992-2000 using SUR. For the full sample, they found a positive relationship between risk and capital. They argued that banks with a higher loan loss reserve tend to have higher capital level. Further, they reported that efficient European banks held less capital and assumed more risk for saving and commercial banks. The empirical results found a negative relationship between risk and capital. They further concluded that efficient banks held more capital than inefficient one. Similarly, Witowschi and Luca (2016) investigated the impact of capital on exposure to risk and banks profitability in seven European Countries using simultaneous equations. They used 68 banks as a sample for the period 2006 to 2011. The results showed a negative relationship between capital and bank risk. The findings revealed a positive relationship between capital and profitability of banks.

In another study, Deelchand and Padgett (2009) used simultaneous equations to investigate relationships between risk, capital, and cost inefficiency of banks for 263 cooperative banks of Japan for 2003-2006. The empirical results indicated that risk and capital were negatively related in Japanese cooperative banks. Further, they revealed that bigger cooperative banks holding small capital were less efficient and more risky.

Zeb and Sattar (2017) investigated the impact of financial regulations on financial soundness and profit efficiency of banks for a sample of 21 commercial banks in Pakistan for the period 2008-2014. They calculated profit efficiency using Data Envelopment Analysis, and financial soundness using Z-score for each bank. They found that profit efficiency was positively related to reserve ratio and non-performing loan to assets ratio of banks. They further proved that loan to deposit ratio and liquidity ratio were positively and significantly related to profit efficiency. Further, they identified that different size of banks had different impact on financial soundness and profit efficiency of banks.

Further, extending the existing literature on the relationship between capital, risk, and efficiency, Bouheni and Rachdi (2014) investigated bank capital with risk taking behavior in commercial banks in Tunisia. However, they used weighted assets to total as a new measure of risk using simultaneous equations approach. They found the negative relationship between capital and risk. They further concluded that larger banks may easily manage their risks by diversification. They found a negative and significant relationship between risk and capital of bank.

Furthermore, Nguyen and Nghiem (2015) investigated interrelationships between default risk, capital ratio and efficiency of banks of India from 1990 to 2011 using SUR. The findings proved that efficiency and capital both were negatively related to default risk. They further argued that public and private banks of India behaved differently regarding the relationship between capital and efficiency. In addition, private banks were found to have low probability of default risk and high greater capital ratio. However, they were less efficient than public banks.

Ayaydin and Karakaya (2014) examined the relationship with capital and profitability 
of 23 Turkish banks using Two-Step System Generalized Method of Moments from 2003 to 2011. However, they found a negative relationship between bank capital and risk, which supports the moral hazard hypothesis. Further, they found a positive relationship between bank capital and risk supporting the regulatory hypothesis. They suggested that banking sector may be improved by attaining the financial efficiency of commercial banks.

Manta and Badircea (2015) examined the relationship among bank capital, risk, and efficiency of 11 Romanian banks for the period 2008 to 2011. They found that risk was significantly and positively related to the capital of banks. This implied that high nonperforming loans portfolio require more capital level. These results also supported the results of Altunbas et al. (2007).

There literature investigating the relationship between bank efficiency, capital, and risk of South East Asian countries are relatively less. Like, Mongid, Tahir, and Haron (2012) investigated the relationship between inefficiency, risk, and capital of commercial banks in Association of South East Asian Nations (ASEAN) for 2003 to 2008 using three-stage least square (3SLS). These countries include Malaysia, Indonesia, Thailand, Singapore, Philippines, Cambodia, Vietnam, and Brunei. The results revealed that capital and bank size have negative relationship with inefficiency of banks whereas risk was not statistically related to inefficiency. Furthermore, they found that in risk model, capital and inefficiency were negatively related to the risk. Similarly, they found that capital and risk were negatively related, whereas, capital and inefficiency were positively related. Bozdo and Mosko (2016) investigated the relationship between efficiency, capital, and risk of commercial banks of Albania for the period 2002-2014 using 3SLS. They found that inefficiency had a positive relationship with the risk of banks and negative relationship between inefficiency and bank capital.

The capital buffer theory recommended that banks tend to hold additional capital than required as an effort to avoid supervisory intervention and market discipline. Brewer, Kaufman, and Wall (2008) examined determinants for the bank capital of USA, Japan, and Europe. They used annual data for unbalance panel of 78 banks from 1992-2005. They found a positive and significant relationship of regulatory, public policy, country financial condition level, macroeconomic and bank-specific variables with the bank capital. They found that high capital ratio was maintained by using better mechanism of corporate governance and the existence of strict capital regulations.

\section{Data Description and Empirical Framework}

\section{Data Description and Sample Selection}

The dataset used in this study consists of 107 banks of SAARC member countries. The data are obtained from Orbis Bank Focus database for the year 2010-2016. The sample includes 18 banks from Pakistan, 3 banks from Afghanistan, 30 banks from India, 23 from Bangladesh, 3 from Bhutan, 11 from Nepal, 3 from Maldives, and 16 from Sri Lanka. 


\section{Variables Description}

The study investigates the relationship between credit risk, bank capital, and inefficiency of SAARC banks. The bank-specific factors included in the study are bank size, return on assets, liquidity, and net lending. The country-specific variables used in the study are return on capital, banking system interest rate spread, banking system liquid assets, and banking system cost. The detail description of variables is given in Table 1.

Table 1a

\begin{tabular}{|c|c|c|}
\hline Variable & Symbol & Description \\
\hline \multicolumn{3}{|l|}{ Bank-specific factors } \\
\hline Inefficiency & INEFF & Total banking Cost to Total Income \\
\hline Credit Risk & LLR & Loan loss reserve to total Assets \\
\hline Capital & ETA & Equity to Total Assets \\
\hline Size & LnTA & Natural Logarithm of total assets \\
\hline Return on Assets & ROA & Net income divided by total assets \\
\hline Net Lending & NLTA & Net loans to Total Assets \\
\hline Liquidity & LIQ & Liquid Assets to total deposits \\
\hline \multicolumn{3}{|l|}{ Country-specific factors } \\
\hline Return on Capital & ROC & Banking system return on Capital \\
\hline Banking system Interest rate Spread & INT & Interest rate spread over treasury bonds in country $\mathrm{j}$ \\
\hline Banking System Liquid Assets & BLIQ & Banking system liquid assets to total assets in country $\mathrm{j}$ \\
\hline Banking System Cost & $\mathrm{BC}$ & Banking system total costs to income ratios in country $\mathrm{j}$ \\
\hline
\end{tabular}

The high bank capital means that banks have a great tendency to absorb loss before it becomes insolvent (Berger \& Bouwman, 2009). The proxy used to calculate bank capital is equity to total assets ratio of a specific bank. Highly capitalized banks operate less efficiently and undertake high risk (Miah \& Sharmeen, 2015; Altunbas et al., 2007). Therefore, we expect a positive relationship of bank capital with inefficiency and risk.

There are different definitions of risk in the literature (Mongid et al., 2012; Bozdo \& Mosko, 2016; Deelchand \& Padgett, 2009). There are different types of risk such as credit risk, market risk, liquidity risk, and operational risk. However, we used credit risk in our study. Therefore, from this point onwards, we will use the term credit risk, instead of only risk. Credit risk is risk of loss when clients fail to fulfill with the terms of a contract or loan. Furthermore, it is not only limited to risk that borrowers are incapable to pay but it also accounts for risk of late payments for banks (Mongid et al., 2012). We used loan loss reserve to total assets as a proxy of credit risk following Altunbas et al. (2007). In general, high risk banks tend to have high revenues thus reducing the efficiency level of the bank. Therefore, we expect a positive relationship of credit risk with inefficiency and bank capital.

We calculate bank cost inefficiency by using accounting measures. The bank cost inefficiency is measured using total banking cost to total income following Mongid et al. (2012). These studies prove that highly capitalized and risky banks operate less efficiently. Regarding the inefficiency, we expect a positive relationship of inefficiency with bank capital.

For explanatory variables, we use a number of bank-specific and country-specific variables. The size of bank is calculated using logarithm of total assets following Alam (2013) and Singh and Sharma (2016). The size of bank is risk sensitive. This means that larger banks reduce risk by diversifying portfolios and management of risk particularly credit 
risk. The large size banks are efficient because they manage large quantity of loan easily. However, large sized bank has less capital than small bank, because public confidence is much higher in big banks. This decreases motivations for higher capital. Therefore, we expect a negative relationship of bank size with inefficiency, credit risk, and bank capital.

Return on asset ratio is used to measure the profitability of banks. Miah and Sharmeen (2015) found that risky and inefficient banks are less profitable and well-capitalized banks are more profitable. Therefore, we expect a positive relationship of return on assets with capital and negative relationship with the inefficiency and credit risk of banks. This study also used net lending as a bank specific factor. The proxy of net lending is calculated using net loans to total assets. The high debt ratio presents high degrees of debt financing. The high net loan to total assets ratio increases risk and decrease efficiency and bank capital (Altunbas et al., 2007). Therefore, we expect a positive relationship of net lending with credit risk and inefficiency and negative relationship with bank capital. More liquid banks are expected to be more efficient and require less capital. Therefore we expect a negative relationship between liquidity and efficiency.

The country-specific variables are included to take account of broad banking system differences. The difference in the interest rates of Treasury bond in different countries may provide opportunities to the investors to gain capital gains. Therefore we included banking system interest rate spread in the study. Different banking systems may have difference in various operations, so we included banking system cost and banking system liquidity.

\section{The Estimation Method}

The modeling framework adopted to estimate the relationship between credit risk, capital, and inefficiency of SAARC banks is used following Altunbas et al. (2007), Jacques and Nigro (1997), and Hughes and Mester (1993). We estimated a system of three models using SUR approach proposed by Zellner (1962). SUR is basically generalization form of linear regression model that consists of several regression equations, each having its own dependent and independent variables. Each equation is a valid linear regression on its own and can be estimated separately, that is why the system is called seemingly unrelated. Further, the error term is supposed to be correlated across the equations. It is commonly used where several regression relationships are examined at the same time.

The inclusion of three models allows for simultaneity between a bank's inefficiency, credit risk, and capital. It is believed that SUR can overcome contemporaneous crossequation error correlation.SUR approach is used for two main reasons. First, it is used to gain efficiency in estimation by combining information on different models. Second, it involves test restrictions of parameters in different models. The models are first applied on all SAARC banks. Then, we repeated the same procedure for each of the SAARC member countries as well to do in-depth analysis.

The estimated models are as follow:

$$
\begin{array}{r}
L L R_{i t}=\alpha+\beta_{1} E T A_{i t}+\beta_{2} L n T A_{i t}+\beta_{3} L I Q_{i t}+\beta_{4} N L T A_{i t}+\beta_{5} I N E F F_{i t}+\beta_{6} I N T_{t}+ \\
\beta_{7} B L I O_{t}+\epsilon_{i t}
\end{array}
$$




$$
\begin{array}{r}
E T A_{i t}=\alpha+\beta_{1} L n T A_{i t}+\beta_{2} L I Q_{i t}+\beta_{3} R O A_{i t}+\beta_{4} N L T A_{i t}+\beta_{5} I N E F F_{i t}+\beta_{6} I N T_{t}+ \\
\beta_{7} B L I O_{t}+\beta_{8} B C_{t}+\beta_{9} R O C_{t}+\epsilon_{i t} \\
I N E F F_{i t}=\alpha+\beta_{1} E T A_{i t}+\beta_{2} L n T A_{i t}+\beta_{3} L I Q_{i t}+\beta_{4} N L T A_{i t}+\beta_{5} L L R_{i t}+\beta_{6} I N T_{t}+ \\
\beta_{7} B L I O_{t}+\beta_{8} B C_{t}+\epsilon_{i t}
\end{array}
$$

The first model explains credit risk $L L R_{i t}$ calculated as loan loss reserves to total assets used for bank $\mathrm{i}$ in year t. The second model explains bank capital ET $A_{i t}$ calculated as equity to total assets for bank i in year t. The third model explains bank cost inefficiency $I N E F F_{i t}$ of bank i in year t, calculated from total bank cost to total income. The other bank-specific variables include size $\operatorname{LnT} A_{i t}$ of bank calculated as logarithm of total assets, return on assets $R O A_{i t}$ calculated as net income divided by total assets, liquidity of bank calculated as liquid assets to total deposits for bank $L I Q_{i t}$ in year $\mathrm{t}$ and net lending measured as net loans to total assets for bank $N L T A_{i t}$ in year t. The country-specific variables included in the study are Interest rate spread over treasury bond $N T_{t}$, banking system liquid assets to total assets in country j $B L I Q_{t}$, return on capital $R O C_{t}$, banking system total costs to income ratios in country $\mathrm{j} B C_{t} . \epsilon$ is the error term for bank i in year t.

\section{Empirical Results and Analysis}

This section describes the summary statistics, model summary, and regression results of SAAR banks.

\section{Summary Statistics of Bank-specific Factors}

Table 1 presents summary statistics i.e., mean value and standard deviation of variables used in the study. The standard deviation is given in the parenthesis.

The summary statistics reveal that the capital of banks of Bhutan has maximum mean of 14.98, whereas, the banks of India had mean value of 7.18. Similarly, having higher mean value of capital for the banks of Bhutan also take risk of 3.44. The summary statistics reveal that mean value of inefficiency for the banks of Afghanistan is found higher followed by the mean value of banks of Pakistan and Sri Lanka. The banks of India are found to have maximum assets having mean value of 7.38 and standard deviation of 0.478 . The mean value of NLTA for the banks of Sri Lanka is 66.76 higher than the banks of other sample selected countries. The mean value of NLTA for the banks of Afghanistan is 18.81 having the standard deviation of 13.09 .

The table consists of summary statistics of variables used in the study. The columns present mean and standard deviation of all the variables used in the study. The standard deviation is given in parenthesis. 
Table 1b

Summary Statistics of bank-specific variables of SAARC

\begin{tabular}{lccccccccc}
\hline Variables & All banks & Pakistan & Afghanistan & India & Bangladesh & Bhutan & Nepal & Maldives & Sri Lanka \\
\hline ETA & 9.680 & 9.530 & 10.62 & 7.180 & 8.900 & 14.98 & 10.03 & 22.90 & 11.78 \\
& -5.200 & -4.510 & -3.920 & -3.510 & -1.940 & -6.830 & -2.960 & -11.91 & -5.670 \\
LLR & 2.290 & 4.240 & 0.938 & 1.041 & 2.300 & 3.440 & 2.190 & 1.990 & 2.570 \\
& -2.040 & -2.170 & -0.644 & -0.770 & -2.360 & -1.470 & -1.670 & -1.600 & -1.670 \\
INEFF & 54.06 & 68.53 & 74.52 & 50.76 & 47.43 & 34.85 & 42.59 & 42.85 & 63.25 \\
& -29.16 & -40.06 & -20.80 & -12.65 & -10.00 & -7.500 & -10.85 & -23.71 & -50.35 \\
ROA & 1.160 & 1.000 & 0.550 & 0.740 & 1.030 & 1.764 & 1.910 & 4.120 & 1.280 \\
& -1.070 & -0.860 & -0.650 & -0.770 & -0.420 & -0.820 & -1.040 & -2.530 & -0.940 \\
\multirow{2}{*}{ LnTA } & 6.430 & 6.490 & 5.500 & 7.380 & 6.290 & 5.410 & 5.660 & 5.240 & 5.900 \\
& -0.790 & -0.460 & -0.360 & -0.470 & -0.150 & -0.400 & -0.200 & -2.530 & -0.590 \\
\multirow{2}{*}{ NLTA } & 56.71 & 39.46 & 18.18 & 59.59 & 64.10 & 53.85 & 64.20 & 35.44 & 66.76 \\
& -13.76 & -7.900 & -13.09 & -4.480 & -7.480 & -6.730 & -9.140 & -6.620 & -6.440 \\
\hline
\end{tabular}

\section{Regression Results}

In this section, we provide the regression results of SUR approach. The overall models are good fit to data and are capable to describe the relationship between credit risk, bank capital, and inefficiency of SAARC banks. Table 2 shows the model summary.

Table 2 shows that model is capable in explaining the relationship between the inefficiency, credit risk, bank capital, and inefficiency of SAARC banks. The model is good fit to data for all SAARC banks, because all Chi-squared values are significant at one percent level. However, in risk model for full sample, the banks of Bangladesh and Sri Lanka show satisfactory explanatory power. All three models possess a very high explanatory power in case of Afghanistan, Bhutan, Nepal, and Maldives. All estimated equations show a good explanatory power in case of Pakistan and India.

\section{Credit Risk Equation}

Table 3 presents the estimates of credit risk (LLR) equation obtained using SUR approach. The table reports that credit risk and inefficiency are negatively related with each other indicated by the negative sign with the coefficients of full sample and banks of sample selected countries except for the banks of Afghanistan and India. The findings revealed that inefficient banks are more reserve constrained as compared to efficient banks. This situation is supported by unsophisticated market where small banks find it difficult to find investment opportunities other than loans.

The result also shows a strong positive relationship between liquidity and credit risk. The result implies that high liquidity level banks leads to the maintenance of high reserve levels by the banks. In other words, the result suggests that banks with high capital and liquidity take on more risk. The results further reveal that bank capital is positively and significantly related to the credit risk. The result implies that increase in capital of banks lead to increase credit risk of the banks. In addition, efficient banks also take on more risk. These findings clearly support the regulatory framework where regulators encourage banks to take on more capital and liquidity to cover the risks born by them. 
Table 2

Model Summary of SAARC Banks

\begin{tabular}{|c|c|c|c|c|c|c|}
\hline Equations & Observation & Parameters & RMSE & $R^{2}$ & $\chi^{2}$ & p-value \\
\hline \multicolumn{7}{|l|}{ All Banks } \\
\hline ETA & 748 & 5 & 4.23 & 0.330 & 18.27 & 0.000 \\
\hline LLR & 748 & 5 & 1.990 & 0.040 & 84.79 & 0.000 \\
\hline INEFF & 748 & 5 & 25.07 & 0.260 & 37.66 & 0.000 \\
\hline \multicolumn{7}{|l|}{ Pakistan } \\
\hline ETA & 126 & 5 & 3.640 & 0.340 & 101.2 & 0.000 \\
\hline LLR & 126 & 5 & 1.820 & 0.290 & 23.11 & 0.000 \\
\hline INEFF & 126 & 5 & 28.40 & 0.490 & 17.27 & 0.000 \\
\hline \multicolumn{7}{|c|}{ Afghanistan } \\
\hline ETA & 21 & 5 & 0.830 & 0.950 & 57.75 & 0.000 \\
\hline LLR & 21 & 5 & 0.120 & 0.960 & 68.20 & 0.000 \\
\hline INEFF & 21 & 5 & 7.940 & 0.840 & 19.42 & 0.000 \\
\hline \multicolumn{7}{|l|}{ India } \\
\hline ETA & 210 & 5 & 3.080 & 0.220 & 85.26 & 0.000 \\
\hline LLR & 210 & 5 & 0.680 & 0.220 & 63.00 & 0.000 \\
\hline INEFF & 210 & 5 & 10.50 & 0.300 & 19.55 & 0.000 \\
\hline \multicolumn{7}{|l|}{ Bangladesh } \\
\hline ETA & 160 & 5 & 1.730 & 0.200 & 18.68 & 0.000 \\
\hline LLR & 160 & 5 & 2.350 & 0.060 & 40.00 & 0.000 \\
\hline INEFF & 160 & 5 & 8.350 & 0.300 & 21.86 & 0.000 \\
\hline \multicolumn{7}{|l|}{ Bhutan } \\
\hline ETA & 21 & 5 & 0.490 & 0.990 & 38.47 & 0.000 \\
\hline LLR & 21 & 5 & 0.260 & 0.960 & 45.65 & 0.000 \\
\hline INEFF & 21 & 5 & 0.820 & 0.980 & 18.76 & 0.000 \\
\hline \multicolumn{7}{|l|}{ Nepal } \\
\hline ETA & 77 & 5 & 1.240 & 0.880 & 48.15 & 0.000 \\
\hline LLR & 77 & 5 & 0.770 & 0.780 & 34.66 & 0.000 \\
\hline INEFF & 77 & 5 & 5.220 & 0.760 & 29.12 & 0.000 \\
\hline \multicolumn{7}{|l|}{ Maldives } \\
\hline ETA & 21 & 5 & 1.470 & 0.890 & 50.71 & 0.000 \\
\hline LLR & 21 & 5 & 0.160 & 0.980 & 51.53 & 0.000 \\
\hline INEFF & 21 & 5 & 2.890 & 0.980 & 46.06 & 0.000 \\
\hline \multicolumn{7}{|l|}{ Sri Lanka } \\
\hline ETA & 112 & 5 & 5.210 & 0.140 & 31.03 & 0.000 \\
\hline LLR & 112 & 5 & 1.640 & 0.020 & 19.72 & 0.001 \\
\hline INEFF & 112 & 5 & 40.46 & 0.340 & 88.90 & 0.000 \\
\hline
\end{tabular}

The credit risk of banks of Afghanistan is negatively related with the size of banks. The estimated coefficient for size suggest that large banks are relatively more capable to reduce credit risk by introducing more diversified portfolio and risk management especially credit risk management. The results also indicate that estimated coefficient of NLTA is negatively significantly related to the credit risk of banks. This result suggests that growth of loan is linked to loan loss reserve less maintained by the banks. The country specific variable banking system interest rate spread suggests an inverse relationship with the risk. Banking system liquidity suggests a positive relationship with the credit risk. The result implies that banks will take on more risk if their liquidity level is high. 
Table 3

Credit Risk (LLRij, as dependent variable)

\begin{tabular}{|c|c|c|c|c|c|c|c|c|c|}
\hline Variables & All banks & Pakistan & Afghanistan & India & Bangladesh & Bhutan & Nepal & Maldives & Sri Lanka \\
\hline \multirow[t]{2}{*}{$E T A_{(i j)}$} & $0.45^{* *}$ & $0.21^{* * *}$ & $0.145^{* * *}$ & $0.32^{* *}$ & $0.61^{* * *}$ & -0.05 & $0.42^{* * *}$ & $0.90^{* * *}$ & 0.32 \\
\hline & -0.17 & -0.04 & -0.01 & -0.11 & -0.1 & -0.1 & -0.04 & -0.16 & -0.24 \\
\hline \multirow[t]{2}{*}{$\left.I N E F F_{(} i j\right)$} & $-0.19^{* * *}$ & $-0.21^{* * *}$ & 0.31 & 0.612 & $-0.72^{* * *}$ & $-0.24 * * *$ & $-0.35^{* * *}$ & $-0.53 * * *$ & $-0.15^{* * *}$ \\
\hline & -0.03 & -0.05 & -0.32 & -0.42 & -0.22 & -0.04 & -0.13 & -0.06 & -0.02 \\
\hline \multirow{2}{*}{$\left.L I Q_{(} i j\right)$} & 0.11 & $0.46^{* * *}$ & $0.33^{* * *}$ & $0.45^{* *}$ & 0.14 & 0.54 & 0.05 & $0.17^{* * *}$ & 0.26 \\
\hline & -0.08 & -0.07 & -0.07 & -0.22 & -0.54 & -0.45 & -0.12 & -0.034 & -0.19 \\
\hline \multirow[t]{2}{*}{$\operatorname{LnT} A_{(i j)}$} & $-0.20^{*}$ & $0.56^{* *}$ & $-0.51^{* * *}$ & $-0.28^{* *}$ & 0.65 & $-0.94 * * *$ & $-0.98^{* *}$ & $-0.68^{* * *}$ & $-0.73^{* *}$ \\
\hline & -0.11 & -0.21 & -0.17 & -0.11 & -1.16 & -0.32 & -0.49 & -0.24 & -0.38 \\
\hline \multirow[t]{2}{*}{$N L T A_{(i j)}$} & -0.72 & $-0.10^{* * *}$ & $-0.30 * * *$ & -0.05 & -0.09 & $-0.18^{* * *}$ & $-0.32^{* * *}$ & $-0.93^{* * *}$ & -0.24 \\
\hline & -0.51 & -0.02 & -0.04 & -0.13 & -0.25 & -0.05 & -0.1 & -0.15 & -0.29 \\
\hline \multirow[t]{2}{*}{$I N T_{(j)}$} & $-0.29^{*}$ & $-0.15^{* * *}$ & -0.41 & $-0.52^{* *}$ & -0.38 & -0.33 & $-0.35^{* *}$ & -0.15 & $0.38^{*}$ \\
\hline & -0.13 & -0.04 & -0.38 & -0.24 & -0.17 & -0.19 & -0.15 & -0.13 & -0.19 \\
\hline \multirow[t]{2}{*}{$B L I Q_{(j)}$} & $0.48^{* *}$ & $0.28^{* *}$ & 0.47 & $0.34^{* *}$ & $0.25^{* *}$ & $0.24^{* *}$ & 0.21 & 0.15 & $0.28^{*}$ \\
\hline & $0.18)$ & -0.12 & -0.35 & -0.1 & -0.09 & -0.09 & -0.13 & -0.13 & -0.15 \\
\hline \multirow[t]{2}{*}{$C O N S$} & 0.37 & $0.42^{* * *}$ & $0.60^{* *}$ & -0.9 & -0.48 & $0.57^{* *}$ & $-0.85^{* * *}$ & -0.57 & $0.76^{* * *}$ \\
\hline & -0.89 & -3.15 & -0.23 & -1.4 & -0.81 & -0.25 & -0.28 & -0.81 & -0.17 \\
\hline Observations & 748 & 126 & 21 & 210 & 160 & 21 & 77 & 21 & 112 \\
\hline $\mathrm{R} \mathrm{Sq}$ & 0.48 & 0.54 & 0.41 & 0.38 & 0.46 & 0.57 & 0.58 & 0.48 & 0.62 \\
\hline
\end{tabular}

Credit Risk model 1 estimates are obtained from the SUR approach. The table presents coefficient and standard error. The standard errors are given in parenthesis. We used Credit Risk $\left(L L R_{i j}\right)$ as dependent variable, calculated as loan loss reserve to total assets. The columns present the results of nine estimations. The bank specific indicators included in the study are: bank capital measured as equity to total assets $\left(E T A_{i j}\right)$, cost inefficiency measured as cost to income ratio $\left(I N E F F_{i j}\right)$, return on assets $\left(R O A_{i j}\right)$, bank size calculated as natural logarithm of total assets $\left(L n T A_{i j}\right)$, and net lending calculated as net loans to total assets $\left(N L T A_{i j}\right)$. The country specific variables used in the model are banking system interest rate spread $\left(I N T_{j}\right)$ and banking system liquidity $\left(B L I Q_{j}\right)$.

\section{Bank Capital Equation}

Table 4 reports the results of bank capital model. The results indicate that credit risk is positively and significantly related to the capital level in case of full sample, and for banks of Pakistan, Bangladesh, Nepal, and Maldives banks. The results indicate that banks that extend more credit risk are usually highly capitalized banks.

The results further provide that bank inefficiency is positively related to bank capital for all banks, Pakistan, India, Nepal, Maldives, and Sri Lanka banks. This result supports the regulatory hypothesis that regulators might permit highly efficient banks to work with a relatively lower capital, and less efficient banks are required to keep high capital base. This result is consistence with the prior studies like Altunbas et al. (2007) and Miah and Sharmeen (2015). These studies also proved that less efficient banks hold more capital than more efficient banks.

The findings further reveal that profitability of SAARC banks is positively and significantly related to the capital level. The positive estimated coefficients ROA indicate that highly profitable banks are well capitalized banks. Further, the results suggest that banks may earn more profit with a higher capital base.

The results further indicate that Size (LnTA) of banks is inversely related to the capital 
of banks. The results are found significant for the banks of Pakistan, Afghanistan, India, Nepal, Maldives, and Sri Lanka. Large banks enjoy more benefits in the forms of bail outs and guarantees to prevent them from default. The theory of "too big to fail" may reduce the intention to inject more capital. In addition, additional capital is also costly to shareholders. They found that small banks own more capital ratio than large banks, further, public confidence is much higher in big banks than small banks and this decreases the motivation for more capital. Similarly, the estimated coefficient of net lending (NLTA) is inversely related with bank capital. The estimated coefficient of NLTA (coefficient=0.82) for the banks of Pakistan indicates that if the other things remain the same; one unit increase in the NLTA may lead to decrease the capital of the bank by 0.82 units. Liquidity levels also appear positively related to capital in most cases. Banking system interest rate spread (INT) seems to have strong positive relationship with bank capital. The results suggest that interest rate yield control bank capitalization. Banking cost (BC) and return on capital (ROC) both are positively and significantly related with the bank capital levels.

Table 4

Bank Capital $\left(E T A_{i j}\right.$, as dependent variable)

\begin{tabular}{|c|c|c|c|c|c|c|c|c|c|}
\hline Variables & All banks & Pakistan & Afghanistan & India & Bangladesh & Bhutan & Nepal & Maldives & Sri Lanka \\
\hline \multirow[t]{2}{*}{$I N E F F_{i j}$} & $0.35^{* *}$ & $0.31^{* * *}$ & 0.21 & $0.92^{* * *}$ & $0.10^{* * *}$ & $0.41^{* * *}$ & $0.13^{* * *}$ & $0.52^{* * *}$ & $0.38^{* * *}$ \\
\hline & -0.16 & -0.12 & -0.27 & -0.19 & -0.01 & -0.09 & -0.01 & -0.04 & -0.12 \\
\hline \multirow[t]{2}{*}{$R O A_{(i j)}$} & $0.74^{* * *}$ & $0.95^{* *}$ & $0.29^{* * *}$ & $0.36^{* * *}$ & $0.76^{* *}$ & $0.28^{* * *}$ & $0.14^{* *}$ & $0.32^{* * *}$ & $0.62^{* * *}$ \\
\hline & -0.15 & -0.35 & -0.07 & -0.14 & -0.37 & -0.04 & -0.05 & -0.15 & -0.23 \\
\hline \multirow[t]{2}{*}{$\operatorname{LnT} A_{(i j)}$} & $-0.77^{* * *}$ & $-0.86^{* * *}$ & $-0.41^{* *}$ & $-0.38^{* *}$ & 0.14 & $-0.57^{* *}$ & $-0.71^{*}$ & -0.53 & $-0.71^{* * *}$ \\
\hline & -0.21 & -0.13 & -0.16 & -0.17 & -0.36 & -0.22 & -0.33 & -0.35 & -0.15 \\
\hline \multirow{2}{*}{$N L T A_{(i j)}$} & -0.14 & $-0.84^{*}$ & $-0.22^{* *}$ & $-0.47^{* *}$ & 0.19 & $-0.52^{* * *}$ & $-0.18^{* * *}$ & $-0.69^{* * *}$ & $-0.15^{*}$ \\
\hline & -0.11 & -0.43 & -0.06 & -0.23 & -0.18 & -0.06 & -0.05 & -0.21 & -0.09 \\
\hline \multirow[t]{2}{*}{$L I Q_{(i j)}$} & 0.2 & $0.86^{* * *}$ & 0.42 & -0.07 & $0.32^{* * *}$ & -0.19 & $0.72^{* * *}$ & $0.70^{* * *}$ & -0.32 \\
\hline & -0.75 & -0.18 & -0.44 & -0.31 & -0.05 & -0.38 & -0.12 & -0.192 & -0.3 \\
\hline \multirow[t]{2}{*}{$B L I Q_{(j)}$} & $0.47^{* * *}$ & 0.28 & 0.68 & 0.45 & 0.1 & 0.24 & 0.64 & 0.27 & 0.03 \\
\hline & -0.12 & -0.15 & -0.54 & $(0.13)^{* *}$ & -0.07 & -0.17 & -0.57 & -0.21 & -0.12 \\
\hline \multirow[t]{2}{*}{$I N T_{(j)}$} & $0.52^{*}$ & 0.64 & 0.41 & $0.48^{* *}$ & $0.19^{*}$ & 0.14 & 0.35 & 0.76 & 0.49 \\
\hline & -0.24 & -0.39 & -0.25 & -0.17 & -0.09 & -0.17 & -0.26 & -0.68 & -0.51 \\
\hline \multirow[t]{2}{*}{$R O C_{(j)}$} & $0.35^{* *}$ & $0.28 * *$ & 0.51 & $0.58 * *$ & 0.26 & 0.33 & 0.58 & 0.69 & 0.35 \\
\hline & -0.14 & -0.09 & -0.37 & -0.14 & -0.27 & -0.45 & -0.39 & -0.51 & -0.17 \\
\hline \multirow[t]{2}{*}{$B C_{(j)}$} & $0.62^{*}$ & 0.23 & 0.46 & $0.36 * *$ & $0.22^{* *}$ & 0.25 & $0.24^{* *}$ & 0.21 & $0.35^{*}$ \\
\hline & -0.33 & -0.13 & -0.38 & -0.17 & -0.09 & -0.37 & -0.11 & -0.24 & -0.19 \\
\hline \multirow[t]{2}{*}{ CONS } & $0.77^{* * *}$ & $0.81^{* * *}$ & $-2.27^{* *}$ & -0.61 & $2.38^{*}$ & $0.46^{* * *}$ & $0.66^{* *}$ & $0.44^{* * *}$ & $0.96^{* *}$ \\
\hline & -0.13 & -0.26 & -1.02 & -6.2 & -1.805 & -0.146 & -0.261 & -0.103 & -0.431 \\
\hline Observations & 748 & 126 & 21 & 210 & 160 & 21 & 77 & 21 & 112 \\
\hline $\mathrm{R} s q$ & 0.56 & 0.42 & 0.51 & 0.46 & 0.54 & 0.39 & 0.54 & 0.35 & 0.46 \\
\hline
\end{tabular}

Bank Capital model 2 estimates are obtained from the SUR approach. The table presents estimated coefficient and standard error. The standard errors are given in parenthesis. We calculated bank capital using equity to total assets $\left(E T A_{i j}\right)$ as dependent variable. The columns present the results of nine estimations. The bank specific indicators included in the study are: credit risk calculated as loan loss reserve to total assets $\left(L L R_{i j}\right)$, cost inefficiency measured as cost to income ratio $\left(I N E F F_{i j}\right)$, return on assets $\left(R O A_{i j}\right)$, bank size calculated as natural logarithm of total assets $\left(L n T A_{i j}\right)$ and net lending measured as loans to total assets $\left(N L T A_{i j}\right)$. The country-specific variables used in the model are banking system interest rate spread $\left(I N T_{j}\right)$, return on capital $\left(R O C_{j}\right)$, and banking $\operatorname{cost}\left(B C_{j}\right)$. 


\section{Bank Inefficiency Equation}

Table 5 presents the estimates of inefficiency model derived from simultaneous equation. The estimates derived for inefficiency model show that bank capital (ETA) is statistically and significantly related to the inefficiency of banks for full sample and also for the individual countries except for Afghanistan. The results imply that efficient banks hold less capital than inefficient banks. The significant relationship between credit risk and bank inefficiency suggest that increase in credit risk makes the bank inefficient. The relationship between credit risk and inefficient is found significant in most of the cases. Similarly, the results reveal that increase in the bank liquidity leads to decrease the inefficiency of banks. The estimates of liquidity are significantly but inversely related with the inefficiency of banks of Pakistan, India, Bangladesh, Nepal, and Sri Lanka. Taken together, increase in liquidity helps banks in undertaking more risky activities but leads to decrease inefficiency.

The size of the bank shows negative relationship with the inefficiency of banks. The results are same for full sample and for sub samples as well. The results imply that increase in size of assets of banks may reduce the inefficiency of banks. Similarly, net lending also provides the similar results. Increases in the net loans to totals loans may decrease inefficiency of banks. The country specific variable banking cost is inversely related with banking inefficiency. Banking system liquidity is positively and significantly related with the bank inefficiency. The result implies that high liquidity may lead banks towards inefficiency.

Table 5

Bank Inefficiency $\left(I N E F F_{i j}\right.$, as dependent variable)

\begin{tabular}{|c|c|c|c|c|c|c|c|c|c|}
\hline Variables & All banks & Pakistan & Afghanistan & India & Bangladesh & Bhutan & Nepal & Maldives & Sri Lanka \\
\hline \multirow[t]{2}{*}{$E T A_{i j}$} & $0.49^{* * *}$ & $0.54^{* * *}$ & 0.86 & $1.09^{* * *}$ & $0.63^{* * *}$ & $0.73^{* * *}$ & $0.94^{* *}$ & $0.85^{* * *}$ & $0.70^{* * *}$ \\
\hline & -0.21 & -0.20 & -0.31 & -0.28 & -0.16 & -0.23 & -0.38 & -0.17 & -0.22 \\
\hline \multirow{2}{*}{$L L R_{i j}$} & $0.73^{* *}$ & $0.54^{* * *}$ & 0.15 & 0.49 & $0.94^{* * *}$ & $0.67^{* * *}$ & $0.63^{* * *}$ & $0.83^{* *}$ & $0.77^{* * *}$ \\
\hline & -0.15 & -0.15 & -0.26 & -0.451 & -0.25 & -0.30 & -0.16 & -0.40 & -0.21 \\
\hline \multirow{2}{*}{$L I Q_{i j}$} & $-0.45^{* * *}$ & $-0.88^{* * *}$ & -0.742 & $-0.59^{* *}$ & $-0.64^{* * *}$ & 0.62 & $-0.53^{* * *}$ & $-0.55^{* * *}$ & $-0.93 * * *$ \\
\hline & -0.21 & -0.17 & -0.813 & -0.14 & -0.15 & -1.24 & -0.06 & -0.16 & -0.15 \\
\hline \multirow{2}{*}{$\operatorname{LnT} A_{i j}$} & $-0.87^{* * *}$ & $-0.72 * * *$ & $-0.83^{* *}$ & $-0.94^{* * *}$ & -0.70 & $-0.40^{* * *}$ & 0.234 & $-0.46^{* *}$ & $-0.87^{* *}$ \\
\hline & -0.21 & -0.30 & -0.4 & -0.15 & -0.47 & -0.14 & -3.39 & -0.2 & -0.25 \\
\hline \multirow[t]{2}{*}{$N L T A_{i j}$} & $-0.26^{* * *}$ & -0.04 & -0.28 & $-0.51^{* * *}$ & $-0.28^{* * *}$ & $-0.88^{* * *}$ & -0.05 & $-0.44^{* *}$ & $-0.79^{* *}$ \\
\hline & -0.06 & -0.39 & -0.50 & -0.17 & -0.08 & -0.14 & -0.07 & -0.2 & -0.39 \\
\hline \multirow{2}{*}{$I N T_{j}$} & $0.23^{* *}$ & $0.32 * *$ & 0.18 & 0.38 & 0.22 & 0.29 & 0.19 & 0.3 & 0.47 \\
\hline & -0.10 & -0.15 & $0.05^{* *}$ & $0.18^{*}$ & 0.32 & 0.44 & 0.08 & 0.12 & 0.19 \\
\hline \multirow[t]{2}{*}{$B C_{j}$} & $-0.39^{* *}$ & -0.33 & -0.23 & -0.12 & -0.33 & -0.23 & -0.69 & -0.36 & 0.24 \\
\hline & -0.16 & 0.25 & $0.12^{*}$ & 0.09 & $0.18^{*}$ & 0.13 & $0.24^{* *}$ & 0.19 & $0.11^{* *}$ \\
\hline \multirow{2}{*}{$B L I Q_{j}$} & $0.56^{* *}$ & $0.42^{*}$ & $0.31^{*}$ & 0.41 & 0.32 & 0.19 & 0.66 & 0.31 & 0.33 \\
\hline & -0.21 & -0.19 & $(0.17)^{*}$ & $(0.16)^{* *}$ & $0.12^{* *}$ & $(0.10)^{*}$ & $0.23 * *$ & 0.24 & 0.41 \\
\hline \multirow[t]{2}{*}{ CONS } & $0.64^{* * *}$ & $0.68^{* * *}$ & $0.59^{* *}$ & $0.72^{* *}$ & $0.72^{* * *}$ & $0.66^{* *}$ & 0.91 & 0.193 & 0.38 \\
\hline & -0.20 & -0.24 & -0.21 & -0.32 & -0.14 & -0.27 & -0.65 & -0.37 & -0.87 \\
\hline Observations & 748 & 126 & 21 & 210 & 160 & 21 & 77 & 21 & 112 \\
\hline $\mathrm{R} \mathrm{Sq}$ & 0.51 & 0.49 & 0.46 & 0.36 & 0.33 & 0.37 & 0.56 & 0.28 & 0.38 \\
\hline
\end{tabular}

Bank inefficiency model 3 estimates are obtained from the $S U R$ estimations. The table presents coefficient and standard error. The standard errors are given in parenthesis. We used Bank Inefficiency (INEFF) as dependent variable calculated as cost to income ratio. The columns present the results of nine estimations. Independent variables are bank capital measured as equity to total assets $(E T A)$, credit risk as loan loss reserve to total assets 
$(L L R)$, return on assets $(R O A)$, bank size as natural logarithm of total assets $(L n T A)$ and net lending as net loans to total assets (NLTA). The country-specific variables used in this model are banking system interest rate spread $\left(I N T_{j}\right)$, banking cost $\left(B C_{j}\right)$, and banking liquidity $\left(B C_{j}\right)$.

\section{Conclusion}

This study examined the relationship between inefficiency, credit risk, and bank capital. The study used 107 banks of eight SAARC countries for the period 2010-2016 using SUR approach. The findings regarding bank inefficiency model suggest a positive and significant relationship with the bank capital. This shows that efficient banks are less capitalized banks than inefficient banks in case of SAARC member countries. We also found a positive and significant relationship between bank risk and bank inefficiency. This implies that excessively risky banks are inefficient banks. There may be one implication of such results that SAARC banks are pressurized by the shareholders for more payouts, these lead inefficient banks to take on more risk.

Our findings further revealed a positive and significant relationship between bank capital and credit risk. This clarifies that highly capitalized banks are excessively risky banks in case of SAARC member countries than less capitalized banks. The results found an inverse relationship between inefficiency and credit risk. The findings of bank capital model reveal that liquidity is positively and significantly related to the capital. The findings suggest that increase in bank capital leads banks towards inefficiency. In other words, taken together increase in inefficiency of banks leads to increase the capital and credit risk. These findings are significant for the regulators and policy makers.

These results adds in the existing literature by providing new insights about the interrelationship between inefficiency, bank capital, and credit risk of SAARC banking sector. The findings may help the management and regulatory authorities in formulating financial regulations to increase the strength of SAARC banking sector with special emphasis on the interrelationship between credit risk, bank capital, and inefficiency. Moreover, regulators and policy makers may plan such strategies that help the banks to increase their level of efficiency and reduce the risk taken by them. In future, we may expand this study to examine the consistency of results by using alternative accounting and market based measures for credit risk, bank capital, and efficiency. 


\section{References}

Alam, N. (2013). Impact of banking regulation on risk and efficiency in islamic banking. Journal of Financial Reporting and Accounting, 11(1), 29-50.

Altunbas, Y., Carbo, S., Gardener, E., \& Molyneux, P. (2007). Examining the relationships between capital, risk and efficiency in European banking. European Financial Management, 13(1), 49-70.

Ayaydin, H., \& Karakaya, A. (2014). The effect of bank capital on profitability and risk in Turkish banking. International Journal of Business and Social Science, 5(1), $252-271$.

Baselga-Pascual, L, A., Antonio Trujillo-Ponce, \& Cardone-Riportell, C. (2015). Factors influencing bank risk in Europe: Evidence from the financial crisis. North American Journal of Economics and Finance, 34(1), 138-166.

Berger, A. N., \& Bouwman, C. H. (2009). Bank liquidity creation. Review of Financial Studies, 22(9), 3779-3837.

Bouheni, B. F., \& Rachdi, H. (2014). Bank capital adequacy requirements and risktaking behavior in Tunisia: A simultaneous equations framework. Journal of Applied Business Research (JABR), 31(1), 231-238.

Bozdo, A., \& Mosko, A. (2016). Modeling the relationship between bank efficiency, capital and risk in Albanian banking system. Procedia Economics and Finance, 39, 319-327.

Brewer, E., Kaufman, G., \& Wall, L. (2008). Bank capital ratios across countries: Why do they vary? Journal of Financial Services Research, 34(2-3), 177-201.

Chen, M., Wu, J., Jeon, B. N., \& Wang, R. (2017). Do foreign banks take more risk? Evidence from emerging economies. Journal of Banking 83 Finance, 82, 20-39.

Deelchand, T., \& Padgett, C. (2009). The relationship between risk, capital and efficiency: Evidence from Japanese cooperative banks. ICMA Centre Discussion Papers in Finance, DP \#2009-2012.. Retrieved from https://doi.org/10.2139\%2Fssrn .1525423

Hughes, J. P., \& Mester, L. J. (1993). A quality and risk-adjusted cost function for banks: Evidence on the "too-big-to-fail" doctrine. Journal of Productivity Analysis, 4(3), 293-315.

Jacques, K., \& Nigro, P. (1997). Risk-based capital, portfolio risk, and bank capital: A simultaneous equations approach. Journal of Economics and Business, 49(6), $533-547$.

Jokipii, T., \& Milne, A. (2011). Bank capital buffer and risk adjustment decisions. Journal of Financial Stability, 7(3), 165-178.

Lee, C., \& Hsieh, M. (2013). The impact of bank capital on profitability and risk in Asian banking. Journal of International Money and Finance, 32, 251-281.

Manta, A., \& Badircea, R. (2015). Empirical study on the relationship between efficiency, capital and risk into the banking system of Romania. Finance: Challenges of the Future, 1(17), 58-67.

Miah, M. D., \& Sharmeen, K. (2015). Relationship between capital, risk and efficiency. International Journal of Islamic and Middle Eastern Finance and Management, 8(2), 203-221. 
Mongid, A., Tahir, I. M., \& Haron, S. (2012). The relationship between inefficiency, risk, and capital: Evidence from commercial banks in ASEAN (Doctoral dissertation, Universiti Putra Malaysia) (Unpublished doctoral dissertation).

Nguyen, T. P. T., \& Nghiem, S. H. (2015). The interrelationships among default risk, capital ratio and efficiency: Evidence from Indian banks. Managerial Finance, 41(5), $507-525$.

Singh, A., \& Sharma, A. (2016). An empirical analysis of macroeconomic and bank-specific factors affecting liquidity of Indian banks. Future Business Journal, 2(1), 40-53.

Witowschi, R. B., \& Luca, F. A. (2016). Bank capital, risk and performance in European banking. A case study on seven banking sectors. Prague Economic Papers, 25(2), $127-142$.

Zeb, S., \& Sattar, A. (2017). Financial regulations, profit efficiency, and financial soundness: Empirical evidence from commercial banks of Pakistan. The Pakistan Development Review, 56(2), 85-103.

Zellner, A. (1962). An efficient method of estimating seemingly unrelated regressions and tests for aggregation bias. Journal of the American Statistical Association, 57(298), $348-368$. 